\title{
Constitution and By-Laws of the American Meteorological Society
}

\author{
1 August 1983
}

\section{CONSTITUTION}

\section{Article I. Name}

This Society shall be called the American Meteorological Society.

\section{Article II. Objects ${ }^{1}$}

The objects of this Society are: The development and dissemination of knowledge of meteorology in all its phases and applications, and the advancement of its professional ideals. The Society shall be a nonprofit organization and none of its net income or net worth shall inure to the benefit of its members. In event of dissolution, any property belonging to the Society shall be donated to some organization or organizations of a similar purpose and character, and in no event shall any of such property be distributed to members of the Society.

\section{Article III. Members'}

1. The membership of the Society shall consist of:

Honorary Members

Fellows

Members

Associate Members

Corporation Members

Student Members

Only Fellows and Members are eligible to vote, to hold office and to be members of the Council with such further limitations as may be imposed by this Constitution and By-Laws. Notwithstanding the preceding sentence those in the grade of Member on December 31, 1965 who became Associate Members on that date are eligible to vote. Professional Members on December 31, 1972 shall be designated Members thereafter.

2. The Council shall elect members to the grades of membership for which they are deemed qualified within the requirements specified in this Article. The Council may delegate the election to non-voting grades, except to the grade of Honorary Member, to such constituent body or elective or appointee officer as it may deem appropriate.

3. Those eligible as candidates for election to Associate

\footnotetext{
${ }^{1}$ Proposed amendments to Articles II and III are set forth on pp. 514-515 of the May 1983 Bulletin of THE AMS, Vol. 64, No. 5.
}

Member shall be persons who are interested in meteorology, climatology or a related discipline.

4. Those eligible as candidates for election to Student Member shall be graduate or undergraduate students in residence at an institution of higher learning at least half time.

5. Those eligible as candidates for election to Member shall satisfy one or more of the following three categories of criteria:

a) hold a baccalaureate or higher degree in the atmospheric or hydrospheric sciences from an accredited institution of higher learning, or hold a degree from such an institution in a related discipline and be employed in the application of his or her knowledge to the advancement of the atmospheric or hydrospheric sciences;

b) hold an associate degree from an accredited community college with a specialization in the atmospheric or hydrospheric sciences to the extent of having successfully completed twenty semester hours of courses in these subjects and have a record of at least three years of professional experience in the application of the atmospheric or hydrospheric sciences of the type normally performed by persons having a baccalaureate degree;

c) during the last ten years preceding the date of the application have a record of at least six years of professional experience in the application of the atmospheric or hydrospheric sciences, of the type normally performed by a person having a baccalaureate degree.

6. Those eligible as candidates for election to Fellow shall have made outstanding contributions to the science or application of meteorology, climatology or other area of atmospheric science during a substantial period of years.

7. Honorary Members shall be persons of acknowledged pre-eminence in the atmospheric sciences either through their own contributions to the science or its applications or through their furtherance of the advance of the atmospheric sciences in some other way. They shall be exempt from all dues and assessments.

8. Corporations and other organizations desirous of supporting the atmospheric sciences are eligible as candidates for election to Corporation Member. 
9. If, in the opinion of the Council after a hearing, a member has infringed any of the Code of Ethics in the By-Laws, he may be censured, suspended or expelled.

\section{Article IV. Elective Offices}

1. The elective officers of the Society shall be:

a) A President, who shall be the immediate past President-Elect.

b) A President-Elect.

2. The term of office of the President and PresidentElect shall be one year.

3. If the office of President becomes vacant, the Council shall elect, from Council membership, a President to fill the remainder of the unexpired term.

4. If the office of President-Elect becomes vacant, the office shall remain vacant until the next general election, at which time a President and President-Elect shall be elected.

5. These Officers, in addition to the duties specifically assigned to them by the Constitution and By-Laws, shall discharge any other duties incident to their respective offices.

\section{Article V. Council}

1. The elective officers, the last two ex-presidents and a total of fifteen other members, shall constitute a Council which shall have general charge of the affairs of the Society. The President shall be Chairman of the Council and the President-Elect shall be Vice-Chairman.

2. Five Councilors shall be elected each year for a term of three years. Four of said Councilors shall be elected by members eligible to vote in accordance with the procedure set forth in Article VI of the Constitution and Article $\mathrm{V}$ of the By-Laws. One of said Councilors shall be elected by the Council of the Society by mail ballot by an affirmative vote of not less than a majority of the entire Council entitled to vote. The ballot shall be mailed to each member of the Council by the Secretary of the Council and to be counted, shall be returned to the Secretary of the Council not later than thirty days after the date the ballot was mailed. The term of office shall commence upon the date said Councilor is elected and shall end when his successor takes office.

3. The Council shall be so constituted that a majority of its members shall not be employed professionally by the same organization.

4. The Council shall appoint upon the recommendation of the President an Executive Director and a SecretaryTreasurer who shall be members of the Council exofficio and without the power to vote. Appointment shall require a vote equal to a majority of the entire Council and removal from office shall be by a vote equal to two-thirds of the entire Council.
5. The President shall nominate and the Council shall elect from the Council membership a Secretary of the Council who shall perform such duties as the Council may direct, including, but not limited to, the signing on behalf of the Council of official notices of nominations, elections and awards, letters of appreciation, letters of censure in code of ethics cases and official requests.

6. The Council may appoint such other officers as may be required.

\section{Article VI. Election of Officers and Councilors}

1. The election of elective Officers and Councilors by members eligible to vote, shall be by mail ballot.

2. At least ninety days prior to the Annual Meeting, the Secretary-Treasurer shall mail to each member eligible to vote a ballot containing the names of the nominees for elective office and councilor. The ballot may contain any questions designated by the Council or by a petition signed by at least fifty members who were eligible to vote on the preceding May 1.

3. The ballots shall be cast by mail and to be counted must be received by the Secretary-Treasurer at the Headquarters of the Society at least thirty days prior to the date of the next Annual Meeting.

If the ballot contains either one or two candidates for the office of President-Elect, the candidate receiving the highest number of votes shall be deemed and declared to be elected to such office; and if there are three or more candidates for said office, the voter shall designate his preference by marking after the name of each candidate a number, starting with the number one, in numerical sequence. In counting the votes, the first choice of each voter shall be counted, and if the sum of said votes for any candidate represents a majority of the number of ballots cast for the office of President-Elect, the candidate receiving said majority vote shall be deemed and declared to be elected. If no candidate has received a majority, then the candidate receiving the least number of votes shall be eliminated from further consideration and the votes of those who voted for said candidate shall be counted for the second choice of said voter. This procedure shall be repeated if necessary until one candidate has received a majority of all ballots cast, in which event he shall be deemed and declared to be elected President-Elect.

If the ballot contains more candidates for Councilor than there are available vacancies, the voter shall indicate his preference by placing a cross beside the names of a corresponding number of candidates, without designating a numerical sequence of preference. Councilors shall be elected to the available vacancies in descending order in accordance with the number of votes received. In the event of any tie vote between two or more candidates for any office, the retiring Council shall choose between said candidates by ballot. 
4. Any elective Officer or Councilor may be removed from office for due cause by a vote of at least two-thirds of the entire Council.

5. The term of office of the elective Officers and Councilors shall commence at the adjournment of the Annual Meeting at which their election is announced and shall end when their successors take office.

6. The Council may lay down additional rules governing elections not inconsistent with the Constitution and By-Laws.

\section{Article VII. Amendments}

1. No part of the Constitution or By-Laws shall be amended or annulled except by mail ballot in the following manner: A proposed amendment shall be ap- proved by the Council or submitted to the SecretaryTreasurer in a petition signed by at least fifty members eligible to vote on the preceding May 1. The proposed amendment with the reasons therefor, shall be published in the official organ of the Society at least ninety days before ballots for the amendment are mailed.

2. A proposed amendment accompanied by a ballot, shall be mailed by the Secretary-Treasurer to each member eligible to vote at least sixty days prior to the date the ballots are to be counted. The ballots to be counted must be received by the Secretary not later than sixty days after they are mailed.

3. The adoption of a proposed amendment shall require the affirmative votes of at least two-thirds of all members voting.

\section{BY-LAWS}

\section{Article I. Dues and Contributions}

1. The dues of all members shall be set by the Council after adequate advance notice to the membership.

2. In order to give proper recognition to members or others making donations to the Society, the Council shall establish appropriate classes of contribution relative to the cumulative amount given by an individual or institution.

3. Any person who is a member of 25 or more years standing will on reaching the age of 70 be relieved of paying dues; if he so requests, without curtailing his rights as a member to receive the publications appropriate to his grade over the last five years.

\section{Article II. Meetings}

1. There shall be an Annual Meeting, between the 25th of December and the 31st of January next following, of the members of the Society at a time and place designated by the Council. Notice of the time and place of the Annual Meeting shall be given by the SecretaryTreasurer not less than sixty days before the date on which the Annual Meeting is held. Other meetings of members shall be held at a time and place designated by the Council and the Secretary-Treasurer shall give notice of the meeting not less than thirty days before the date on which the meeting is held.

2. The rules contained in "Robert's Rules of Order Revised" shall govern the meetings of the Society unless inconsistent with the Constitution, By-Laws or any standing rules of the Society.

A quorum for the transaction of business at a meeting shall be at least fifty members present who are eligible to vote. The affirmative vote of a majority of the members present who are eligible to vote shall be required for the resolution of any question.

The Council may make other rules for meetings not inconsistent with the Constitution or By-Laws. Business not set forth in the notice of the meeting shall not be transacted if five members eligible to vote object.

3. Local chapters or other bodies of the Society may be organized with the consent of the Council, and the Council shall promulgate rules governing their activities. The Council may withdraw its consent for good cause.

4. The fiscal year of the Society shall conform to the calendar year.

5. If the Council, at its first meeting after a meeting of the members of the Society, determines that any resolution adopted by the members affects the fundamental rights of the membership, then such resolution shall be submitted immediately by mail ballot to all members eligible to vote. Approval shall require the affirmative vote of a majority of those voting. The ballots to be counted, shall be received by the Secretary-Treasurer within thirty days of the date mailed.

\section{Article III. Council}

1. The Council shall meet at the close of the Annual Meeting. The President may convoke the Council in special meeting at such time as he may deem advisable for promoting the affairs of the Society. A special meeting of the Council shall be called by the President whenever requested in writing by five or more members of the Council. Notices of all special meetings shall state the purpose or purposes for which such meetings are called. At least thirty days written notice of the place 
and date of any special meeting shall be given by the Secretary-Treasurer to each member of the Council.

2. A member of the Council must be present to be entitled to vote. A quorum for the transaction of any business at a meeting shall be eleven members of the Council eligible to vote. An affirmative vote of a majority, but not less than eight, of the Councilors present shall be required for the resolution of any question, unless the matter is one which by express provision of the Constitution or By-Laws, requires a greater proportion, in which event such express provision shall control.

3. Business of the Council may be transacted by mail ballot at the direction of the President. The ballot shall be mailed to each member of the Council and the ballots to be counted shall be returned to the Secretary-Treasurer not later than thirty days after the date the ballot was mailed. An affirmative vote of not less than twothirds of the Council shall be required for the resolution of any question by mail ballot. If, on the date the ballots are to be counted, the Secretary-Treasurer has received in writing from five or more Councilors, a request with the reasons therefor, that the vote be postponed, the postponement will take place and the matter at issue shall be submitted to a second vote in accordance with the procedure set forth in the two preceding sentences.

If the President declares that action by the Council is urgent, he may direct that a vote be taken by telephone or telegram, provided that telegraphic confirmation is received from each Councilor voting by the SecretaryTreasurer within a time determined by the President.

4. The corporate powers of the Society shall be vested in the Council subject to the Constitution and By-Laws of the Society.

\section{Article IV. Constituent Bodies}

1. There shall be an Executive Committee which shall consist of:

a) The President, who shall be the Chairman;

b) The President-Elect, who shall be the Vice Chairman;

c) The immediate Past-President;

d) The Secretary of the Council;

e) Two members of the Council, other than those named in the preceding paragraphs a), b), c), and d), who shall be elected by the Council, one each year for a term of two years;

f) The Executive Director and Secretary-Treasurer, both ex-officio and without the power to vote.

2. A majority of the voting members, at least one of whom shall be the President or President-Elect, of the Executive Committee shall constitute a quorum. The affirmative vote of a majority of the voting members present at a meeting of the Executive Committee shall be required for the resolution of any question.
3. The Executive Committee shall function as the executive arm of the Council within the policies established by the Council. The Committee shall meet as often as it deems necessary and it is empowered to interpret and execute Council policies when the Council is not in session.

4. Other constituent bodies such as Commissions, Boards, and Committees of the Society may be established by the Council with such membership and terms of reference as the Council may from time to time decide.

5. The names, purposes, membership, terms of office of members and terms of reference to all constituent bodies established by the Council shall be published. This publication shall be brought up to date at least annually by the issue of amendments or by such other means as may be determined by the Council.

\section{Article V. Nomination of Officers and Councilors}

1. The Council shall arrange for the nomination of candidates for each elective office and Council position to be filled. The report thereon, together with the written consent of each nominee, shall be submitted by May 1 of each year to the Secretary-Treasurer who shall give the report, not later than the next following July 15 , to all members eligible to vote. Nominations also may be made by petition signed by at least fifty members eligible to vote on the preceding May 1 , provided the petition is received by the Secretary-Treasurer together with the written consent of the nominee, not later than the next following September 1.

\section{Article VI. Appointed Officers}

1. The Society shall maintain a permanent headquarters and business office under the direction of an Executive Director appointed by the Council, with appropriate responsibilities including those listed below:

a) Conduct such business and correspondence of the Society as may be directed by the Council;

b) Under suitable bond, disburse the funds of the Society in accordance with policies determined by the Council;

c) Serve as an ex-officio non-voting member of all Commissions, Boards, and Committees established by the Council.

2. The Secretary-Treasurer will serve and be responsible to the Council and be administratively responsible to the Executive Director. He should have appropriate experience in legal and accounting matters. He will serve as parliamentarian for the Council meetings, internally audit the financial, legal, and correspondence functions of the Society, record Society proceedings, issue calls to meetings of the Council, send notifications of Council actions, and prepare and keep current a Policy Reference Book bringing together all the current policies of the Society as established by recorded Council actions for the guidance and knowledge of all Society members. 


\section{Article VII. Publications}

1. The Society shall publish an official organ and such additional journals, papers, books, and the like as may be authorized by the Council.

\section{Article VIII. Code of Ethics}

In order to protect the public interest; to enhance the usefulness of the meteorological and related professions to humanity; to uphold the dignity and honor of the profession and to provide guidance for individual members, corporate members, or for members in association with other professionals, the American Meteorological Society has adopted the following Code of Professional Ethics for compliance by the Society's membership.

\section{A. Relationship with the profession as a whole.}

1. The member will conduct himself in a manner to reflect dignity and honor on his profession.

2. The member will endeavor to keep abreast of scientific and technical developments within the professions, and will constantly strive for improvements.

3. He will endeavor to contribute new knowledge to the profession by making known to the scientific world results of his significant work or research through the media of technical or scientific publications or meetings.

B. Relationship of the member to fellow professionals.

1. He will not take credit knowingly for work done by others; in publications or meetings, he will attempt to give credit where due.
C. Relationship of the member with his clients and the general public.

1. He will base his practice on sound scientific principles applied in a scientific manner.

2. He will not direct his professional activities into practices generally recognized as being detrimental to or incompatible with the general public welfare.

3. Before undertaking work for compensation, he will fully advise his client as to the probability of success.

4. He will refrain from making exaggerated and unwarranted claims and statements, for example:

a) Long-range predictions which demonstrate little or no skill over climatology shall be identified as outlooks, experimental predictions, or climatological expectancies, as appropriate,

b) Stated claims for skill and accuracy of predictions must be based on verification by valid statistical techniques,

c) General purpose forecasts will not be represented as being adequate for specific operations which are better served by specialized forecasts,

d) Claims for results from weather modification must be backed by data and prior testing to demonstrate that the claimed results might reasonably be expected.

5. He will not use or display the official seal of the American Meteorological Society unless duly authorized by the Society.

6. The member, regardless of organization affiliation, will refer requests for service which are beyond his professional capabilities or his scope of service to those properly qualified. 